\title{
OPERATOR'S WHOLE BODY VIBRATIONS DEPENDENT OF AGROTECHNICAL SURFACE, SPEED OF MOVEMENT AND SEAT UPHOLSTERY
}

\author{
Željko BARAČ, Ivan PLAŠČAK, Tomislav JURIĆ, Mladen JURIŠIĆ, Domagoj ZIMMER, Ivan VIDAKOVIĆ, \\ Davor PETROVIĆ, Vinko DUVNJAK, Monika MARKOVIĆ
}

\begin{abstract}
The paper presents the recorded vibrations that affect the operator's body when an agricultural tractor moves along three types of agrotechnical surfaces, i.e. asphalt, an alfalfa field, and a field path, and when seven different tractor seat upholsteries are used. The research was performed in accordance with the HRN ISO 2631-1 and HRN ISO 2631-4 standards. The tractor used in the research was an IMT 560 and the duration of the measurement was 30 minutes, which was repeated three times for every tractor seat upholstery type. The research was exploitative. The measurements were performed using an MMF VM30 meter. The paper reveals a different level of vibrations in dependence with different surfaces and seat upholsteries. The fewest vibrations were produced by asphalt, and the best upholsteries are memory foam and sponge.
\end{abstract}

Keywords: agricultural tractor; agrotechnical surfaces; seat upholstery; vibrations

\section{INTRODUCTION}

Vibrations are generally considered to be oscillatory motions of a mechanical system. Oscillation is a periodical motion around an equilibrium point, i.e. a motion that repeats itself after a certain period. Vibrations are a result of dynamic forces in machines with moving parts, as well as in the structures linked to machines. In the beginning, the insignificant vibrations can cause a resonance in some other parts of the structure and they can increase and become the main and rather serious source of increased vibrations and noise. Different machine parts vibrate at different amplitudes and frequencies. Vibrations cause material fatigue and wear. They are often a cause of machine defects [1].

The vibrations transferred to the operator's body, i.e. whole-body vibrations occur when the body leans against a vibrating surface, e.g. when the driver is sitting on a vibrating chair, standing on a vibrating floor, or lying on a vibrating surface [2].

The authors [3] posit that the most important machine component regarding the influence of vibrations is the seat as operators spend most of their time in a seated position. Seat construction, the back of the operator, the depth of the seat, and the upholstery of the seat can exert a complex impact on the operator's ability to operate the machine, as well as on the occurrence of occupational diseases. The same authors claim that the seat upholstery wears out in time so that it is necessary to mend it. A defective seat cannot ensure proper sitting posture, which can cause occupational diseases. Overexposure to mechanical vibrations can have a negative impact on the human body, e.g. overexposure to high vibrational frequencies can lead to physical problems such as spinal dysfunction [3].

The authors [4] in their research claim that a suspended front axle of a tractor generally dampens the vibrations transferred to the operator's seat. The vibrations decrease on average from $13 \%$ to $15 \%$ but they may be reduced as much as $30 \%$. The authors [5] suggest that a seat suspension has been almost a universal feature of agricultural tractors during the last 30 years. The suspension system was introduced to enable the operator to manage the machine in a more comfortable and easier way, which has resulted in increased work productivity. The authors [6] argue that operators might drive tractors for as long as twelve hours a day, which can cause back problems. The analysis of vibrations produced by agricultural machinery is complex as it depends on many factors. The abovementioned authors emphasize that tyre pressure and seat suspension affect vibrations. The authors [7] posit that tractor speed, tyre pressure and the distribution of the transported weight are the most crucial factors that affect the comfort of a tractor operator riding on a tractor that moves along an asphalt surface. Lower tyre pressure is more comfortable for the operator; however, it is not always possible to lower tyre pressure for distinct reasons, one of the most important being the quality of the surface along which the tractor is moving. The authors [8] claim that air seat reduces both high and low vibration frequencies. The same authors argue that low vibration frequencies can be reduced by assembling an air container next to the seat or onto the cabin. The authors [9] suggest that the sitting posture of the driver, i.e. the position of his legs during driving is in significant connection with the sitting comfort.

The authors [10] conducted a research on Masey Ferguson tractors using the limits of vibration exposure as a criterion. They established that after an eight-hour exposure to vibrations, the allowed limit was not exceeded. Additionally, they claim that it is important to bear in mind that in certain situations, some frequencies pertaining to axles do exceed the permitted limits. Thus, it was concluded that seats can absorb vibrations and create ergonomically proper work conditions. The study was performed on an asphalt surface. The authors [11] conducted a study on vibrations on two tractors. One tractor was a newer model with a cabin, whereas the other was an older model without 
a cabin. It was concluded that it is easier to measure vibrations on a tractor without a cabin and that the engine itself is the greatest source of vibrations in both tractors. The cabin was emphasized as an important part of tractor equipment because it protects the operator from vibrations, dust, and the objects that might appear in the operator's vicinity. Higher vibration levels were established on the older tractor.

The aim of the research is to measure the levels of vibrations that affect the operator's body when an agricultural tractor moves on various agrotechnical surfaces at various speeds in dependence with different upholsteries of the tractor seat. Additionally, the aim is to establish potential interdependencies. It is hypothesized that due to a tractor's movement along various agrotechnical surfaces in dependence with different seat upholsteries, the level of vibrations affecting the operator's body will increase.

\section{MATERIALS AND METHODS}

MMF VM30-H is the measuring device used for the measurement of mechanical vibrations that affect the body of the operator when an IMT 558 agricultural tractor is in motion. The tractor moved along three different surfaces, namely asphalt, an alfalfa field, and a field path. The following are the seat upholsteries on which the driver sat: a seat without an upholstery (i.e. only a metal seat framework), cork, styrofoam, sponge, memory foam, cotton wool, and air cushion, Tab. 1. Each measurement was repeated three times. The motion speed was 4,5 and 6 $\mathrm{km} / \mathrm{h}$. The research shown here was exploitative. The measurements were performed in 2017 in a period of 20 days. The average daytime air temperature in the days when the measurements took place ranged between $18^{\circ}$ and $19^{\circ}$, whereas the relative humidity was between $58 \%$ and $60 \%$.

Table 1 Characteristic of the seat upholstery material

\begin{tabular}{|c|c|c|}
\hline Type & Main characteristic & Thickness \\
\hline Industrial Cork & density $110-120 \mathrm{kgm}^{-3}$ & $100 \mathrm{~mm}$ \\
\hline $\begin{array}{c}\text { Viscoelastic polyurethane } \\
\text { memory foam }\end{array}$ & density $80 \mathrm{kgm}^{-3}$ & $100 \mathrm{~mm}$ \\
\hline $\begin{array}{c}\text { Expanded polystyrene (EPS) - } \\
\text { Styrofoam }\end{array}$ & density $15 \mathrm{kgm}^{-3}$ & $100 \mathrm{~mm}$ \\
\hline Polyuretan sponge & density $35 \mathrm{kgm}^{-3}$ & $100 \mathrm{~mm}$ \\
\hline Cotton wool cushine & density $120 \mathrm{gm}^{-3}$ & $100 \mathrm{~mm}$ \\
\hline Orthopedic PVC air cushion & diameter $330 \mathrm{~mm}$ & $100 \mathrm{~mm}$ \\
\hline
\end{tabular}

The research was performed in accordance with the standards [12] and [13]. The measurements were performed while the driver was sitting in accordance with the standard [12]. The seat therefore represents the contact point between the operator and the tractor. The measuring device was set in the exact position in accordance with the operators sitting position. It was set onto the seat so that the axes were recorded in the following directions [12]: $x$ axis: longitudinally (along the axis of motion - forward (positive) / backward (negative), $y$ axis: laterally (at the right angle to the motion direction) and $z$ axis: vertically, upward (positive) / downward, vertically to the surface (negative). The vibrations were recorded based on a coordinate system for particular body parts. The device recorded the vibrations that were directly transferred through the seat to the operator's body.

According to [14], the limit values for the daily level of vibration exposure were established. The limit value for the vibration transferred to the body of the operator is 1.15 $\mathrm{m} / \mathrm{s}^{2}$. Wd and $\mathrm{Wk}$ are the weight filters used in the measurements. Wd is used for vibration measurement in the direction of the $x$ and $\mathrm{y}$ axes in the sitting position, whereas Wk refers to the vibrations in the direction of the $x$ axis.

The R.M.S. measurement method used for the measurement in motion accounts for the occasional impulse and transient vibrations. It applies a short integral time constant. The size of vibrations is defined as a maximum transient vibration value (MTVV), which is the maximum for $a_{w}\left(t_{0}\right)$.

$a_{w}\left(t_{0}\right)=\left\{\frac{1}{\tau} \int_{t_{0}-\tau}^{t_{0}}\left[a_{w}(t)\right]^{2} d t\right\}^{\frac{1}{2}}$

$a_{w}(t)$ - the current frequency of the recorded acceleration $\left(\mathrm{m} / \mathrm{s}^{2}\right)$,

$\tau$ - time of integration for the current averaging,

$t$ - time (s),

$t_{0}$ - time of observation (s).

$M T V V=\max \left[a_{w}\left(t_{0}\right)\right]$

MTVV - maximum transient vibration value $\left(\mathrm{m} / \mathrm{s}^{2}\right)$

The measured values were statistically analyzed using an application for statistical analysis in the MS Office Excel 2013, and IBM SPSS Statistics v.19.0.1. The paper shows the descriptive statistical values and multiple analysis of variance (MANOVA). Multiple correlations and the regresion equation in this analysis were perfomed.

\section{RESULTS AND DISCUSSION}

The measurement of vibrations for the upholstery-free seat produced on the asphalt surface resulted in the occurrence of the maximum vibration value recorded in the direction of the $y$ axis at all motion speeds. The lowest recorded value was established in the direction of the $x$ axis at all speeds (Fig. 1). Furthermore, a conspicuously highest level of vibrations was recorded on the alfalfa field in the direction of the $x$ axis at all speeds, whereas the lowest level was recorded in the direction of the $z$ axis at $4 \mathrm{~km} / \mathrm{h}$, with all other values being the same. The vibrations recorded on the field path were the lowest in the direction of the $z$ axis at all speeds, whereas the highest value was recorded in the direction of the $x$ axis at $4 \mathrm{~km} / \mathrm{h}$. All other values were identical.

The highest level of vibrations for the cork seat (Fig. 2) was established in the direction of the $\mathrm{y}$ axis at all motion speeds on the asphalt surface, whereas the lowest recorded value for the same surface occurred in the direction of the $x$ axis at $4 \mathrm{~km} / \mathrm{h}$, while all other values were the same. 
Additionally, the highest recorded values on the field path happened in the direction of the $z$ axis at $5 \mathrm{~km} / \mathrm{h}$ ) and at 6 $\mathrm{km} / \mathrm{h}$ in the direction of all three axes.

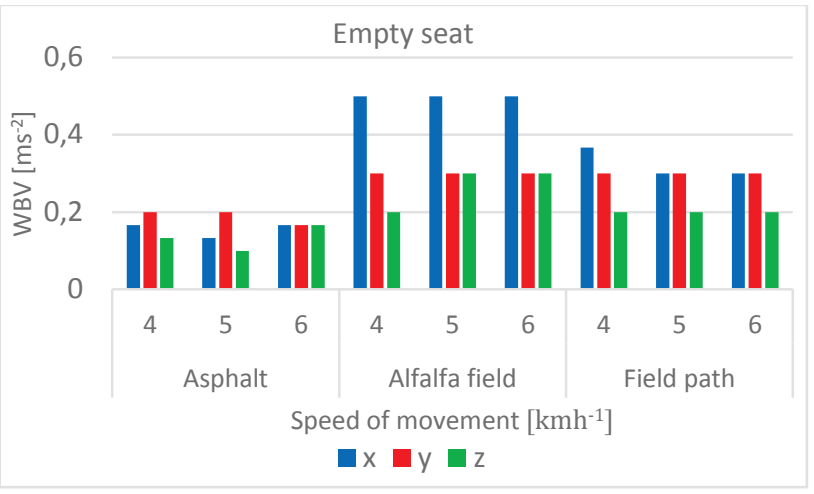

Figure 1 Measured vibration data - empty seat

Fig. 3 shows the highest levels of vibrations recorded on the asphalt surface in the direction of the $y$ axis at all motion speeds, whereas the lowest values were recorded in the direction of the $x$ axis at all motion speeds as well as in the direction of the $z$ axis at 5 and $6 \mathrm{~km} / \mathrm{h}$.

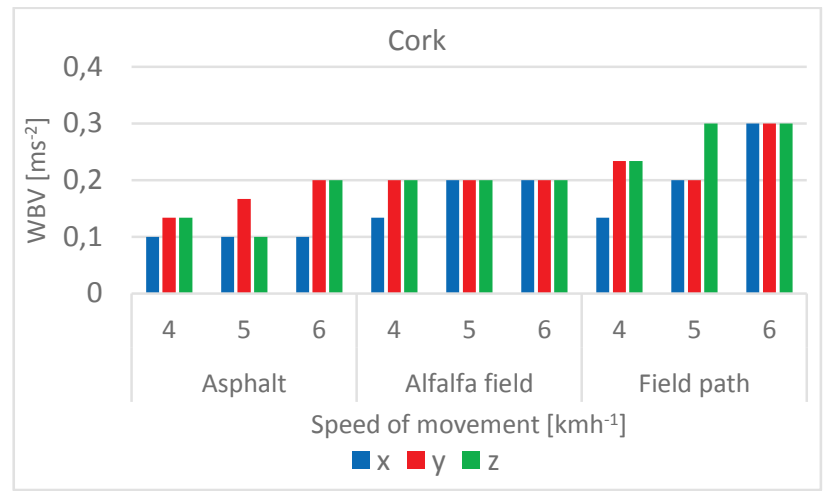

Figure 2 Measured vibration data - cork seat

The highest values of vibrations on the alfalfa field were found in the direction of the $z$ axis at all speeds, while all other vibration values were the same.

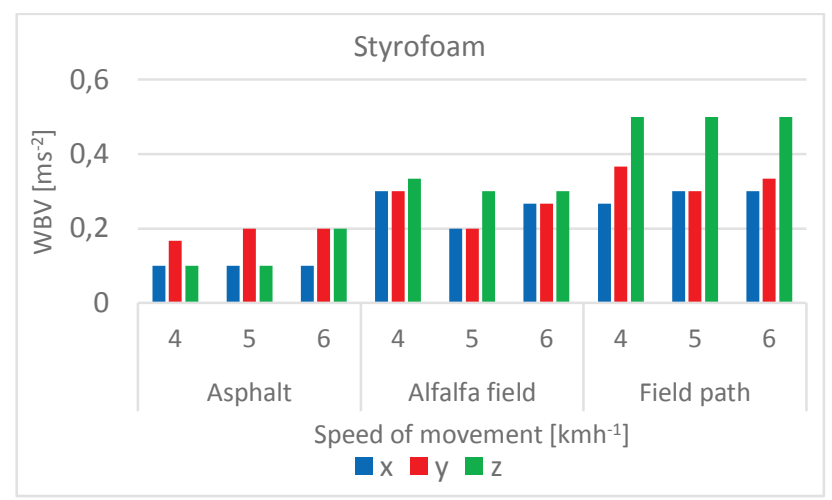

Figure 3 Measured vibration data - Styrofoam seat

The vibration measurement for sponge (Fig. 4) resulted in the highest values on the asphalt surface in the direction of the $x$ axis at $4 \mathrm{~km} / \mathrm{h}$, while the lowest value was recorded in the direction of the $y$ axis at 4 and $5 \mathrm{~km} / \mathrm{h}$, while all other values were the same. Moreover, the highest level of vibrations was recorded on the alfalfa field in the direction of the $x$ axis at all speeds as well as in the direction of the $z$ axis at 5 and $6 \mathrm{~km} / \mathrm{h}$, whereas the lowest value was recorded in the direction of the $y$ axis at $4 \mathrm{~km} / \mathrm{h}$, while all other values were the same. The vibrations recorded on the field path are the lowest in the direction of the $y$ axis at all speeds, whereas the highest value was recorded in the direction of the $z$ axis at all motion speeds and in the direction of the $x$ axis at $6 \mathrm{~km} / \mathrm{h}$. All other vibration values were the same.

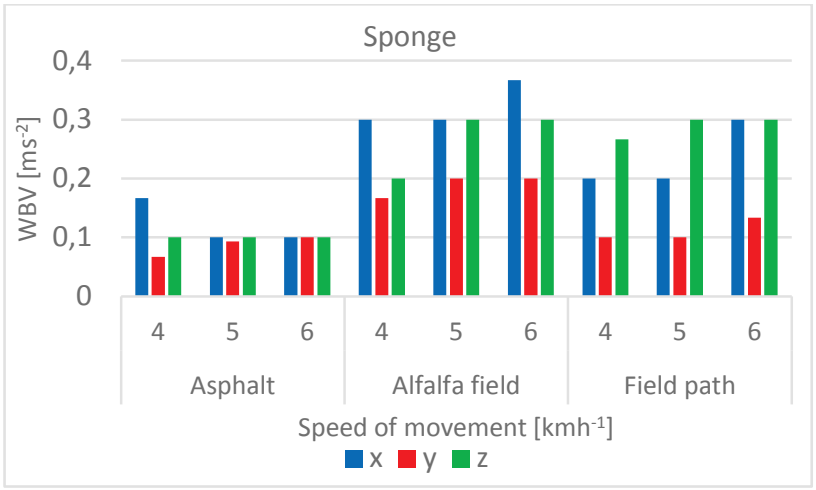

Figure 4 Measured vibration data - sponge seat

The vibrations recorded on memory foam (Fig. 5) have the same values on the asphalt surface in the direction of all three axes and at all motion speeds. The highest vibration value was recorded on the alfalfa field in the direction of the $z$ axis at all speeds and in the direction of the $x$ axis at 5 $\mathrm{km} / \mathrm{h}$, while all other values were the same. The lowest level of vibrations on the field path was recorded in the direction of the y axis at all speeds, whereas the highest value was recorded in the direction of the $z$ axis at $6 \mathrm{~km} / \mathrm{h}$. All other vibrations had the same values.

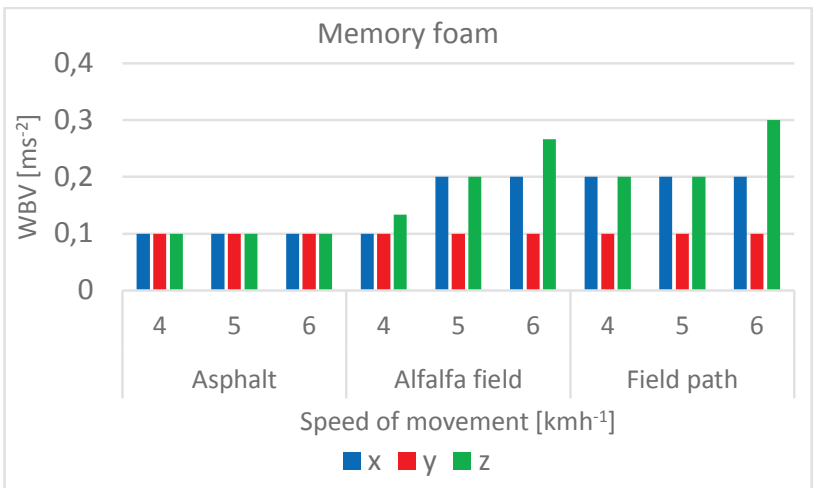

Figure 5 Measured vibration data - memory foam seat

The vibrations recorded on cotton wool (Fig. 6) have the same values on the asphalt surface in the direction of all three axes and at all motion speeds. The highest vibration value was recorded on the alfalfa field in the direction of the $x$ axis at all speeds and in the direction of the $z$ axis at 6 $\mathrm{km} / \mathrm{h}$, while the lowest value was recorded in the direction of the $y$ axis at all speeds and in the direction of the $z$ axis at 
$4 \mathrm{~km} / \mathrm{h}$. Moreover, the lowest level of vibration was recorded on the field path in the direction of the y axis at all speeds, while the highest values were recorded in the direction of the $z$ axis at all speeds and in the direction of the $x$ axis at 5 and $6 \mathrm{~km} / \mathrm{h}$.

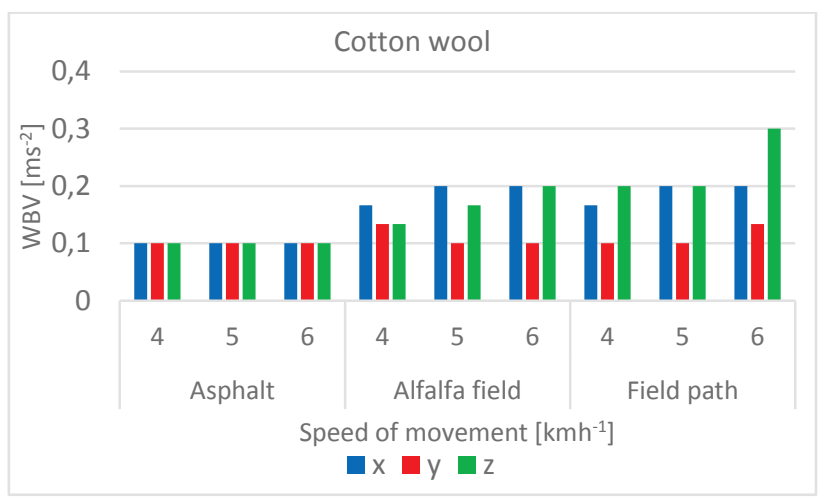

Figure 6 Measured vibration data - cotton wool seat

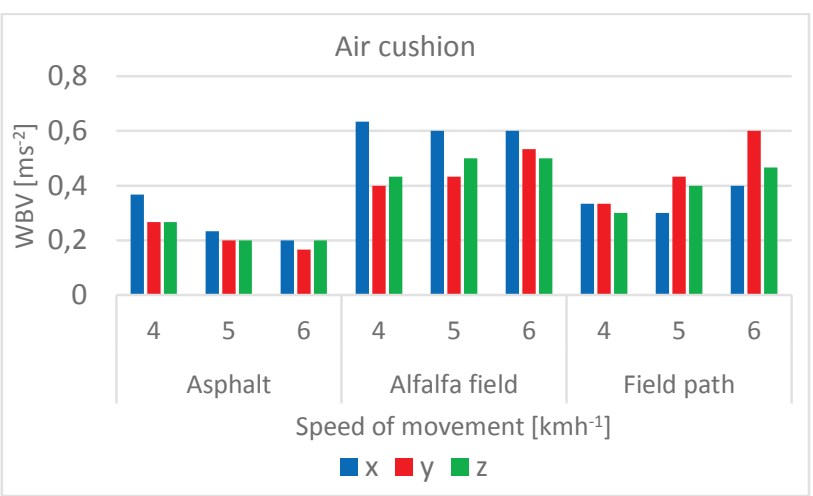

Figure 7 Measured vibration data - air cushion seat

The vibrations recorded on the air cushion (Fig. 7) on an asphalt surface show the highest values in the direction of the $x$ axis at all speeds and in the direction of the $z$ axis at $6 \mathrm{~km} / \mathrm{h}$, while the lowest level was recorded in the direction of the $y$ axis at $6 \mathrm{~km} / \mathrm{h}$ at all speeds, while all other values were the same. Furthermore, the highest vibration level was recorded on the alfalfa field in the direction of the $x$ axis at all speeds, whereas the lowest was recorded in the direction of the $y$ axis at 4 and $5 \mathrm{~km} / \mathrm{h}$, as well as in the direction of the $z$ axis at $6 \mathrm{~km} / \mathrm{h}$. The vibrations recorded on the field path show the lowest value in the direction of the $z$ axis at 4 $\mathrm{km} / \mathrm{h}$ and in the direction of the $x$ axis at 5 and $6 \mathrm{~km} / \mathrm{h}$. The highest value was recorded in the direction of the $x$ axis at 4 $\mathrm{km} / \mathrm{h}$ and in the direction of the $y$ axis at all speeds.

Tab. 2 shows the statistical significance of all tested effects and their interaction in the direction of the $x$ axis, with the impact of the independent variables 'seat upholstery' and 'agrotechnical surface' being highly significant, and the impact of the independent variable 'motion speed' being significant. The mutual interaction of all three independent variables is highly significant.

The impact of all independent variables in the direction of the $y$ axis is highly significant. The interaction of the independent variables ('agrotechnical surface', 'motion speed') is significant, whereas it is highly significant for all other variables (Tab. 3).

The impact of all three independent variables in the direction of the $z$ axis is generally highly significant, which is shown in Tab. 4. Moreover, the interaction of the independent variables ('seat upholstery', 'motion speed') is significant, while it is highly significant for all other variables.

Tab. 5 shows the correlation coefficient, the connection between a dependent and independent variable (i.e. the vibrations that impact the body of the operator in the direction of the $x, y$, and $z$ axes). Additionally, according to [15], the actual significant connection in the direction of the $z$ axis is discernible, whereas the connection in the direction of the $x$ and $y$ axis is slight.

Table 2 Tests of Between - Subjects Effects - Dependent Variable: xos

\begin{tabular}{|c|c|c|c|c|c|c|c|c|}
\hline Source & Type III Sum of Squares & $d f$ & Mean Square & $F$ & Sig. & Partial Eta Squared & Noncent. Parameter & Observed Power $^{\mathrm{b}}$ \\
\hline Corrected Model & $3.340^{\mathrm{a}}$ & 62 & 0.054 & 42.423 & 0.000 & 0.954 & 2630.250 & 1.000 \\
\hline Intercept & 10.290 & 1 & 10.290 & 8103.375 & 0.000 & 0.985 & 8103.375 & 1.000 \\
\hline Seat_upholstery & 1.533 & 6 & 0.256 & 201.250 & 0.000 & 0.906 & 1207.500 & 1.000 \\
\hline Agrotechnical_surface & 1.007 & 2 & 0.503 & 396.500 & 0.000 & 0.863 & 793.000 & 1.000 \\
\hline Motion_speed & 0.012 & 2 & 0.006 & 4.625 & 0.012 & 0.068 & 9.250 & 0.772 \\
\hline $\begin{array}{c}\text { Seat_upholstery* } \\
\text { Agrotechnical_surface }\end{array}$ & 0.609 & 12 & 0.051 & 39.938 & 0.000 & 0.792 & 479.250 & 1.000 \\
\hline $\begin{array}{c}\text { Seat_upholstery* } \\
\text { Motion_speed }\end{array}$ & 0.066 & 12 & 0.006 & 4.333 & 0.000 & 0.292 & 52.000 & 1.000 \\
\hline $\begin{array}{c}\text { Agrotechnical_surface } \\
\text { * Motion_speed }\end{array}$ & 0.045 & 4 & 0.011 & 8.875 & 0.000 & 0.220 & 35.500 & 0.999 \\
\hline $\begin{array}{c}\text { Seat_upholstery* } \\
\text { Agrotechnical_surface } \\
\text { Motion_speed }\end{array}$ & 0.068 & 24 & 0.003 & 2.240 & 0.002 & 0.299 & 53.750 & 0.995 \\
\hline Error & 0.160 & 126 & 0.001 & & & & & \\
\hline Total & 13.790 & 189 & & & & & & \\
\hline Corrected Total & 3.500 & 188 & & & & & & \\
\end{tabular}


Table 3 Tests of Between - Subjects Effects - Dependent Variable: yos

\begin{tabular}{|c|c|c|c|c|c|c|c|c|}
\hline Source & Type III Sum of Squares & $d f$ & Mean Square & $F$ & Sig. & Partial Eta Squared & Noncent. Parameter & Observed Power $^{\mathrm{b}}$ \\
\hline Corrected Model & $2.472^{\mathrm{a}}$ & 62 & 0.040 & 22.161 & 0.000 & 0.916 & 1373.951 & 1.000 \\
\hline Intercept & 7.957 & 1 & 7.957 & 4421.901 & 0.000 & 0.972 & 4421.901 & 1.000 \\
\hline Seat_upholstery & 1.653 & 6 & 0.276 & 153.129 & 0.000 & 0.879 & 918.772 & 1.000 \\
\hline Agrotechnical_surface & 0.301 & 2 & 0.150 & 83.571 & 0.000 & 0.570 & 167.141 & 1.000 \\
\hline Motion_speed & 0.023 & 2 & 0.011 & 6.299 & 0.002 & 0.091 & 12.599 & 0.891 \\
\hline $\begin{array}{c}\text { Seat_upholstery* } \\
\text { Agrotechnical_surface }\end{array}$ & 0.305 & 12 & 0.025 & 14.140 & 0.000 & 0.574 & 169.682 & 1.000 \\
\hline $\begin{array}{c}\text { Seat_upholstery* } \\
\text { Motion_speed }\end{array}$ & 0.055 & 12 & 0.005 & 2.547 & 0.005 & 0.195 & 30.558 & 0.967 \\
\hline $\begin{array}{c}\text { Agrotechnical_surface } \\
\text { * Motion_speed }\end{array}$ & 0.022 & 4 & 0.005 & 3.053 & 0.019 & 0.088 & 12.213 & 0.793 \\
\hline $\begin{array}{c}\text { Seat_upholstery* } \\
\text { Agrotechnical_surface } \\
\text { * Motion_speed }\end{array}$ & 0.113 & 24 & 0.005 & 2.624 & 0.000 & 0.333 & 62.986 \\
\hline Error & 0.227 & 126 & 0.002 & & & & & 0.999 \\
\hline Total & 10.656 & 189 & & & & & & \\
\hline Corrected Total & 2.699 & 188 & & & & & & \\
\hline
\end{tabular}

Table 4 Tests of Between - Subjects Effects - Dependent Variable: zos

\begin{tabular}{|c|c|c|c|c|c|c|c|c|}
\hline Source & Type III Sum of Squares & $d f$ & Mean Square & $F$ & Sig. & Partial Eta Squared & Noncent. Parameter & Observed Power $^{\text {b }}$ \\
\hline Corrected Model & $2.546^{\mathrm{a}}$ & 62 & 0.041 & 59.697 & 0.000 & 0.967 & 3701.231 & 1.000 \\
\hline Intercept & 10.478 & 1 & 10.478 & 15232.692 & 0.000 & 0.992 & 15232.692 & 1.000 \\
\hline Seat_upholstery & 0.890 & 6 & 0.148 & 215.538 & 0.000 & 0.911 & 1293.231 & 1.000 \\
\hline Agrotechnical_surface & 1.020 & 2 & 0.510 & 741.769 & 0.000 & 0.922 & 1483.538 & 1.000 \\
\hline Motion_speed & 0.078 & 2 & 0.039 & 56.385 & 0.000 & 0.472 & 112.769 & 1.000 \\
\hline $\begin{array}{c}\text { Seat_upholstery * } \\
\text { Agrotechnical_surface }\end{array}$ & 0.407 & 12 & 0.034 & 49.308 & 0.000 & 0.824 & 591.692 & 1.000 \\
\hline $\begin{array}{c}\text { Seat_upholstery* } \\
\text { Motion_speed }\end{array}$ & 0.017 & 12 & 0.001 & 2.000 & 0.029 & 0.160 & 24.000 & .905 \\
\hline $\begin{array}{c}\text { Agrotechnical_surface } \\
\text { * Motion_speed }\end{array}$ & 0.029 & 4 & 0.007 & 10.462 & 0.000 & 0.249 & 41.846 & 1.000 \\
\hline $\begin{array}{c}\text { Seat_upholstery * } \\
\text { Agrotechnical_surface } \\
\text { * Motion_speed }\end{array}$ & 0.106 & 24 & 0.004 & 6.423 & 0.000 & 0.550 & 154.154 & 1.000 \\
\hline $\begin{array}{c}\text { Error } \\
\text { Total }\end{array}$ & 0.087 & 126 & 0.001 & & & & & \\
\hline Corrected Total & 13.110 & 189 & & & & & & \\
\hline
\end{tabular}

Table 5 Coefficient of variation dependent variable $x, y$ and $z$ axes

\begin{tabular}{|c|c|c|c|c|}
\hline Model & $r$ & $\begin{array}{c}r^{2} \\
\text { Square }\end{array}$ & $\begin{array}{c}\text { Adjusted } r^{2} \\
\text { Square }\end{array}$ & $\begin{array}{c}\text { Std. Error of } \\
\text { the estimate }\end{array}$ \\
\hline \multicolumn{5}{|c|}{ xos } \\
\hline 1 & 0.379 & 0.144 & 0.130 & 0.12727 \\
\hline 2 & 0.309 & 0.095 & 0.081 & 0.11488 \\
\hline \multicolumn{5}{|c|}{ yis } \\
\hline 3 & 0.633 & 0.401 & 0.391 & 0.09233 \\
\hline
\end{tabular}

\section{CONCLUSION}

The two-way variance analysis generally shows that the impact of the two independent variables 'seat upholstery' and 'agrotechnical surface' in the direction of the $\mathrm{x}$ axis is highly significant in relation to the dependent variable. The impact of the independent variable 'motion speed' is significant. The interaction of all independent variables is highly significant.

Additionally, the impact of all three independent variables in the direction of the y axis is highly significant, the interaction of the independent variables 'agrotechnical surface' and 'motion speed' is significant, and the impact of all other independent variables is highly significant. The impact of all three independent variables in the direction of the $z$ axis is highly significant, while the interaction of the independent variables 'seat upholstery' and 'speed motion' is significant. For all other independent variables, the impact is highly significant.

The correlation coefficient shows a connection among dependent variables (i.e. the vibrations that affect the operator's body in the direction of the $x, y$, and $z$ axes) and the independent variables for which an actual significant correlation in the direction of the $z$ axis was established, while a slight correlation was established in the direction of the $x$ and y axes.

The published research shows that none of the recorded vibration values that affect the operator's body exceeded the limit value of $1.15 \mathrm{~m} / \mathrm{s}^{2}$.

\section{REFERENCES}

[1] Tanković, A., Suljić-Beganović, F., Talajić, M., Lutvica, S., Lutvica, E., \& Goletić, A. (2015). Effect of vibrations on human body. Bulletin of Medical Chamber, 20, 33-40

[2] Fahy, F. \& Thompson, D. (2016). Fundamentals of sounds and vibration, $2^{\text {rd }}$ ed. Institute of sounds and vibration research, Southampton, U. K. Bergs, J. \& Kanaska, D. (2012). Motor vehicle seats and their defect classification. Engineering for rural development, Proceedings of the $11^{\text {th }}$ International scientific conference, Jelgava, May 2012, 314318 
[3] Marsili, A., Ragni, L., Santuro, G., Servadio, P., \& Vassalini, G. (2002). PM-Power and Machinery: Innovative Systems to reduce Vibrations on Agricultural Tractors: Comparative Analysis of Acceleration transmitted through the Driving Seat. Biosystems Engineering, 81(1), 35-47. https://doi.org/10.1006/bioe.2001.0003

[4] Scarlett, A. J., Price, J. S., \& Stayner, R. M. (2007). Wholebody vibration: Evaluation of emission and exposure levels arising from agricultural tractors. Journal of Terramechanics, 44, 65-73. https://doi.org/10.1016/j.jterra.2006.01.006

[5] Deboli, R., Calvo, A., \& Preti, C. (2017). Whole-body vibration: Measurement of horizontal and vertical transmissibility of an agricultural tractor seat. International Journal of Industrial Ergonomics, 58, 69-78. https://doi.org/10.1016/j.ergon.2017.02.002

[6] Cutini, M., Romano, E., \& Bisaglia, C. (2010). Effect of tyre pressure and wheel loads on whole-body vibration characteristics of tractors. International Conference, Work Safety and Risk Prevention in Agro-Food and Forest Systems, Ragusa, September 2010, 431-436.

[7] Hostens, I., Deprez, K., \& Ramon, H. (2004). An improved design of air suspension for seats of mobile agricultural machines. Jurnal of sound and vibration, 276(1-2), 141-156. https://doi.org/10.1016/j.jsv.2003.07.018

[8] Grujicic, M., Pandurangan, B., Arakeres, G., Bell, W. C., He, T., \& Xiw, X. (2009). Seat-cushion and soft-tissue material modeling and a finite element investigation of the seating comfort for passenger-vehicle occupants. Materials and Design, 30(10), 4273-4285. https://doi.org/10.1016/j.matdes.2009.04.028

[9] Baesso, M. M., Martins, G. A., Barsso, R. C. E., \& Fischer, S. J. C. (2014). Noise and Vibration of Tractors: An Ergonomic Evaluation. International Journal of Applied Science and Technology, 4(4), 46-54.

[10] Almeida, S. V., Sperotto, F. C. S., Doimo, L. S., Correia, T. P. S., Santos, J. E. G., \& Silva, P. R. A. (2015). Analysis of vibration levels in agricultural tractor with and without cabin. African Journal of Agricultural Research, 53(10), 4945-4949.

[11] HZN (1999). Mechanical vibration and shock -- Evaluation of human exposure to whole-body vibration -- Part 1: General requirements, HRN ISO 2631-1. Croatian Standards Institute, Zagreb, 1999.

[12] HZN (2010). Mechanical vibration and shock -- Evaluation of human exposure to whole-body vibration -- Part 4: Guidelines for the evaluation of the effects of vibration and rotational motion on passenger and crew comfort in fixed-guideway transport systems, HRN ISO 2631-4. Croatian Standards Institute, Zagreb, 2010.

[13] EC (2002). Council Directive on the minimum health safety requirements regarding the exposure of workers to the risks arising from physical agents (vibration), J Eur Commun, EEC 89/391, 2002/44.

[14] Petz, B., Kolesarić, V., \& Ivanec, D. (2012). Petz Statistics Basic Statistical Methods for Non-mathematicians. Senat Sveučilišta u Zagrebu, Zagreb.
Authors' contacts:

Željko BARAČ, MSc, Assistant

Faculty of Agriculture

Vladimira Preloga 1, 31000 Osijek

zbarac@pfos.hr

Ivan PLAŠČAK, PhD, Assistant Professor

Faculty of Agriculture

Vladimira Preloga 1, 31000 Osijek

iplascak@pfos.hr

Tomislav JURIĆ, PhD, Full Professor

Faculty of Agriculture

Vladimira Preloga 1, 31000 Osijek

tjuric@pfos.hr

Mladen JURIŠIĆ, PhD, Full Professor

Faculty of Agriculture

Vladimira Preloga 1, 31000 Osijek

mjurisic@pfos.hr

Domagoj ZIMMER, MSc, Assistant

Faculty of Agriculture

Vladimira Preloga 1, 31000 Osijek

dzimmer@pfos.hr

Ivan VIDAKOVIĆ, MSc, Assistant

Faculty of Agriculture

Vladimira Preloga 1, 31000 Osijek

ividakovic@pfos.hr

Davor PETROVIĆ, MSc, Assistant

Faculty of Agriculture

Vladimira Preloga 1, 31000 Osijek

dpetrovic@pfos.hr

Vinko DUVNJAK, PhD, Scientific Adviser

Agricultural Institute Osijek

Južno predgrađe 17, 31000 Osijek

vinko.duvnjak@poljinos.hr

Monika MARKOVIĆ, PhD, Assistant Professor

Faculty of Agriculture

Vladimira Preloga 1, 31000 Osijek

mmarkovic@pfos.hr 